\title{
HEALTH AND RETIREMENT DECISIONS AN UPDATE OF THE LITERATURE
}

\author{
MATTHIAS DESCHRYVERE
}

ENEPRI RESEARCH REPORT NO. 6

MARCH 2005

ENEPRI Research Reports are designed to make the results of research projects undertaken within the framework of the European Network of Economic Policy Research Institutes (ENEPRI) publicly available. This paper was prepared as part of the ENEPRI projects on Ageing Health and Retirement in the EU (AGIR) and the Research Training Network on Health, Ageing and Retirement (REVISER), financed by the European Commission's $5^{\text {th }}$ Framework Programme, DG Research, contract no. HPRN-CT-2002-00330. Its findings and conclusions should be attributed only to the author and not to ENEPRI or any of its member institutes.

ISBN 92-9079-559-X

AVAILABLE FOR FREE DOWNLOADING FROM THE ENEPRI WEBSITE (HTTP://WWW.ENEPRI.ORG) 


\title{
HEALTH AND RETIREMENT DECISIONS AN UPDATE OF THE LITERATURE
} ENEPRI RESEARCH REPORT NO. 6/MARCH 2005 MATTHIAS DESCHRYVERE*

\begin{abstract}
This paper surveys the relation between the labour supply and the health of the elderly, based on major studies conducted earlier and new literature. Most of the empirical literature on the topic is drawn from American data, although new European datasets have enabled analysis in several EU countries. The paper complements previous surveys in that it includes recent European results and overviews most of the latest developments in micro-modelling issues. The quest for unbiased estimates of the effect of health on retirement is characterised by several challenges. One important challenge is the endogenous character of the relationship between health and retirement. A second challenge concerns the reporting bias to which certain health measures may be prone. The empirical literature surveyed suggests that poor health reduces the capacity to work and has a substantial impact on labour force participation. The exact magnitude, however, is sensitive to both the choice of health measures and the identification assumptions. For that reason a comparison of health effects between different studies is difficult. Nevertheless, what has been proven is that the old assumption that objective health measures are superior to subjective health measures needs to be applied with caution.
\end{abstract}

JEL classification: I10, J22, J26

Keywords: health, labour supply, retirement and retirement policies

\footnotetext{
* Matthias Deschryvere has undertaken this research with the Research Institute of the Finnish Economy (ETLA), Lönnrotinkatu 4B 00120 Helsinki, Finland, e-mail: deschryvere@fonds.org. The author wishes to express his gratitude to Uwe Jensen, Jukka Lassila, Jorgen Mortensen and Hannu Piekkola.
} 


\section{Contents}

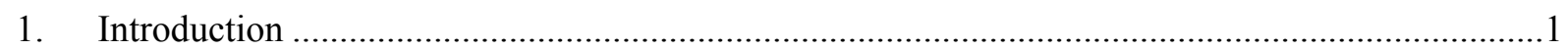

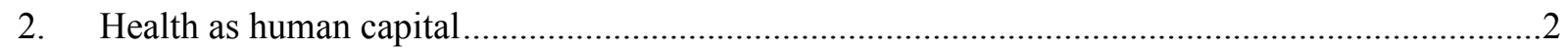

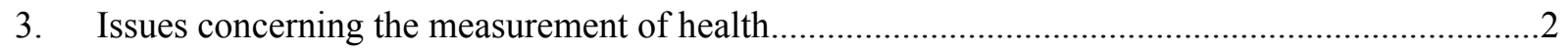

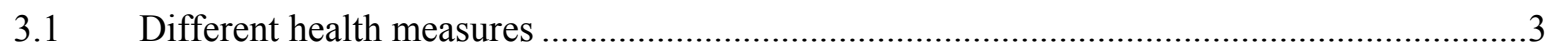

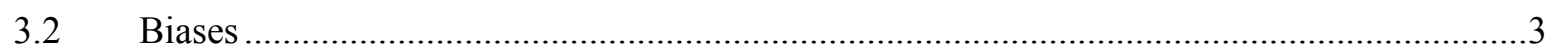

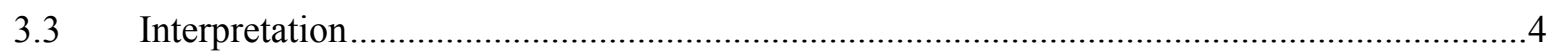

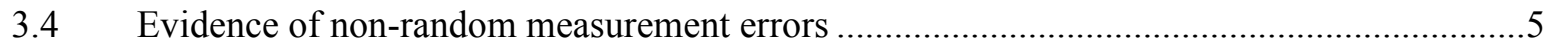

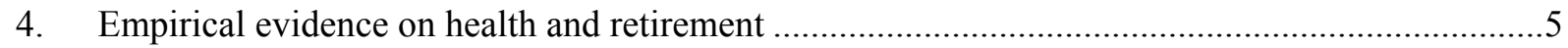

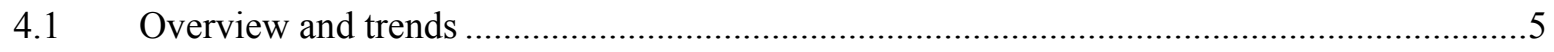

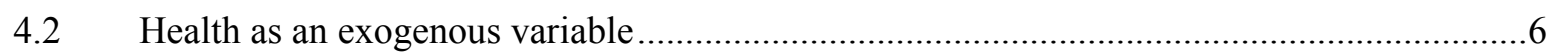

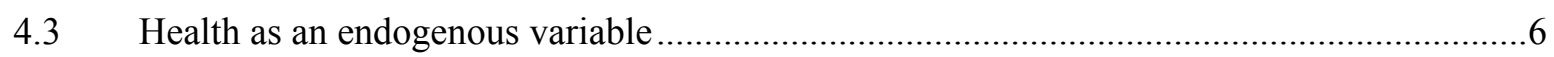

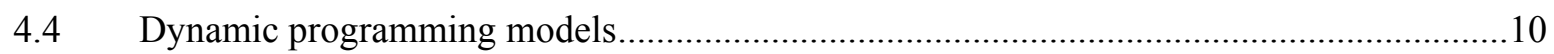

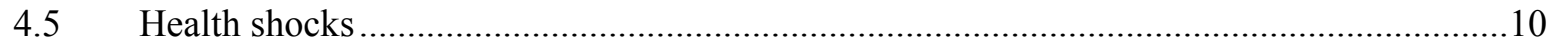

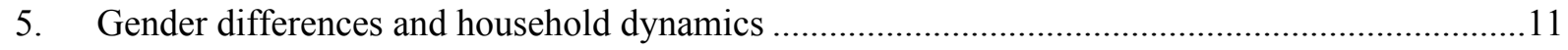

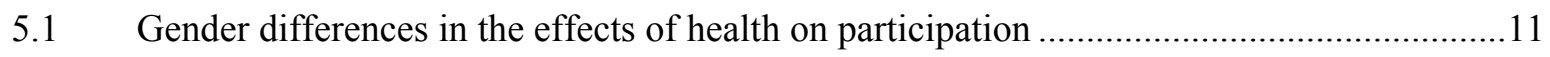

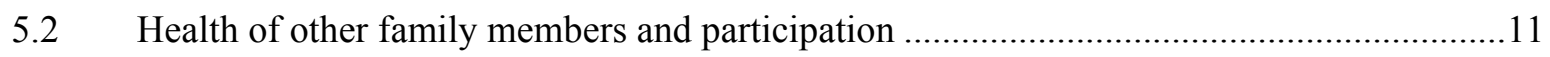

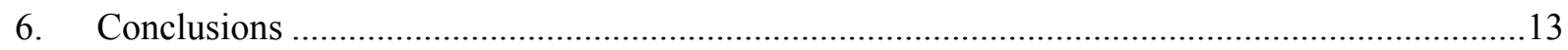

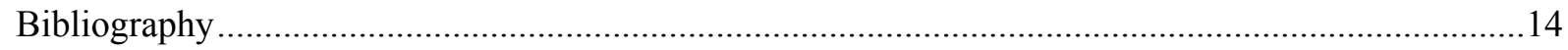

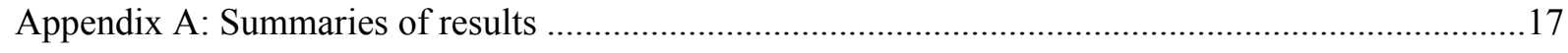

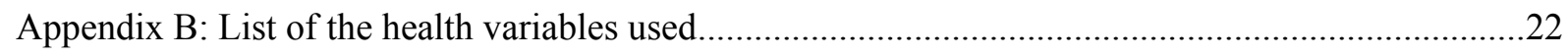

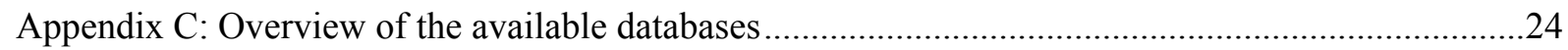

Appendix D: Relation between health and labour force participation .............................................26 


\title{
HEALTH AND RETIREMENT DECISIONS AN UPDATE OF THE LITERATURE
}

\author{
MATTHIAS DESCHRYVERE
}

\section{Introduction}

In 1984 Anderson and Burkhauser wrote that the appropriateness of the use of self-reported health measures was "the major unsettled issue in the empirical literature on the labour supply of older workers" (Anderson \& Burkhauser, 1984). During the last 20 years, the relation between health and labour force participation has been widely studied for developing countries (see Strauss \& Thomas, 1998). As developed countries have higher life expectancies, more developed pension systems and disability benefit channels, it is important to consider these two factors separately. In a volume of the Handbook of Labour Economics, Currie and Madrian (1999) wrote an excellent chapter covering the very many links between health, health insurance and the labour market. In that chapter they also summarised the results of 31 studies covering the relation between health and labour force participation. Their chapter is recommended reading and this report is to a certain extent based on its content and its structure. There are, however, some important value-adding differences in the approach taken here. Currie and Madrian concentrated mainly on evidence from the US and summarised findings from the literature of the 1980s and the first half of the 1990s. This survey covers the latest literature on developed countries and seeks to complement previous work with a focus on evidence from European countries. A further difference is that we select only one specific health topic, namely the relation between the health and labour force participation of the elderly.

The literature suggests that health has an effect on most outcomes of interest to labour market economists, including wages, earnings, labour force participation, hours worked, retirement, job turnover and benefit packages. For certain groups, such as single mothers and older persons, health is thought to be a major determinant of wages, hours and labour force participation. Certainly health is very important in retirement decisions, although there is no consensus about the magnitude of its impact or about its size relative to the effects of other variables. It is important to distinguish between health events that lead to an inability to explain retirement decisions fully and declining health status, which leaves the option to stay in the labour market. To get an idea of the likelihood and timing of a retirement decision it is crucial to control for the health of an individual. An understanding of the effects of health on labour market activity is important for three other reasons: first, to assist in evaluating the cost-effectiveness of interventions designed to prevent or cure disease; second, to help assess the effectiveness and viability of such programmes, given that the relation between health and labour market participation is mediated by other social programmes; and third, in the context of population ageing, more individuals will reach the age where health has the greatest impact on labour market outcomes.

Incorporating health problems into a standard retirement model is complex. Health status, defined as the physical and mental ability to perform work, is likely to affect the timing of retirement in many ways. Poorer health often has a negative impact on productivity, can reduce earnings and affect preferences. Its effect on the utility of consumption and leisure are relevant too. Health also influences individuals' remaining time horizon, in that some conditions alter life expectancy and hence the number of years available to choose between work and retirement (Grossman, 1972). To sum up, the predicted effects of poor health on the optimal retirement age are theoretically ambiguous (Sammartino, 1987).

Based on empirical evidence we can conclude that poor health leads to earlier retirement because its effects on preferences and productivity dominate. The empirical literature on health and retirement can be divided into three categories based on the health variables included in the retirement model: 1) selfreported health status or self-reported work limitations; 2) objective measures of health such as information on medical conditions or subsequent mortality; and 3) instruments for self-reported 
measures using objective measures. Through recent empirical studies the understanding of the relation between health and retirement has become clearer, although there are problems in that it is very difficult to obtain unbiased estimates (see Appendix D for an overview). While the traditional health of Europeans has improved and its impact on the labour force participation of the elderly has weakened, declining psychological well-being and institutional changes may explain why health factors are still a major determinant of retirement.

The structure of the paper is as follows. Section 2 approaches health as human capital and section 3 covers health measurement issues. Section 4 describes the empirical evidence on the relation between health and retirement. Section 5 handles gender differences and dynamics within households. The overall conclusions are presented in section 6 .

\section{Health as human capital}

Becker (1964) compared investment in "health capital" with other forms of human capital such as education. Grossman (1972) elaborated that idea. In his model consumers are assumed to maximise an inter-temporal utility function. The stock of health today depends on past investments in health and on the rate of depreciation of health capital. Health is valued by consumers both for its own sake and because being sick is assumed to take time away from market and non-market activities. Non-market time is an input into both health production and the production of other valued non-market goods such as leisure activities. His model can be solved to yield a conditional labour supply function in which labour supply depends on the endogenous health variable. From an empirical point of view, the main implication of the model is that health must be treated as an endogenous choice. As many of the investments made in health occur later in life, endogeneity in health may be a greater potential source of bias than the endogeneity of education.

Most of the literature treats health as an exogenous variable. The assumption is that exogenous shocks to health are the dominant factor creating variation in health status in developed countries. This may be reasonable as current health depends on past decisions and on habits that may be very difficult to break and the fact that individuals have imperfect information about the health production function at the time of making decisions. Yet relatively little research has been devoted to assessing the empirical importance of the potential endogeneity bias. Examples include Bound (1991), Bound et al. (1999) and the more recent analysis of Lindeboom and van Doorslaer (2003).

There are several reasons why poorer health status will, ceteris paribus, reduce the probability of continued work:

1) it may raise the current disutility of work;

2) it reduces the return from work if there is a relationship between poor health and low wages; and

3) it may entitle the individual to non-wage income such as disability benefits, which is contingent on not being in work.

An opposite effect can evolve if poor health raises consumption requirements and requires higher income than the received disability insurance benefits. If on the other hand poorer health is associated with lower life expectancy, the annualised consumption available from existing wealth is raised and may induce earlier retirement.

\section{Issues concerning the measurement of health}

The concept of health has been compared to the concept of 'ability' - everyone has some idea what is meant by the term but it is remarkably difficult to measure. Failure to properly measure health leads to a bias similar to the ability bias (Griliches, 1977) in standard human capital models. The degree of the health bias can vary with different health measures and discerning an idea of its magnitude may be as difficult as in the case of the ability bias (Currie \& Madrian, 1999, pp. 3313-14). 


\subsection{Different health measures}

Ideally we need a measure of health that relates to labour force participation in that it covers the 'work capacity'. Currie and Madrian (1999) divide the usual health measures into eight categories:

1) health status (very good, good, fair, bad or very bad);

2) whether there are health limitations on the ability to work;

3) whether there are other functional limitations such as problems with activities of daily living (ADLs);

4) the presence of chronic and acute conditions;

5) the utilisation of medical care;

6) clinical assessment of such things as mental health or alcoholism;

7) nutritional status (height, weight and body mass index); and

8) expected or future mortality.

Studies concentrating on developing countries usually use the latter four measures whereas studies of developed countries mostly use the first five. The choice of measure should largely depend on the question underpinning the research, although it is always necessary to check for robustness as different measures may produce different results. A relevant example of the need for robustness checks on different measures is that the physical health of Europeans has been improving but that the mental health has been deteriorating (Ettner et al., 1997).

\subsection{Biases}

Estimates of the effects of health on labour supply are quite sensitive to the measure used. Each measure can vary in at least two ways. The first of these captures the link between productivity and health. A stronger link should increase the explanatory power of regression models. The second reveals that certain measures may be more subject to reporting biases. The main problem with measures is not that they fail to correlate well enough with 'work capacity' but that the measurement error is unlikely to be random. Other potential problems with survey measures that lead to different kind of biases include:

- Responses may not be independent of labour market outcomes (endogeneity/overestimates). Individuals who reduced their participation or exited the labour force may have a higher probability of reporting that they have a poor health status, functional limitations, various conditions or that they utilise health care. There are two main reasons for that:

- They may mention health limitations to justify their reduced labour supply or to rationalise behaviour. The so-called 'justification hypothesis' suggests that estimated health effects using subjective measures may be unreliable if individuals use health as a justification for leaving the labour force early (Bound, 1991; Anderson \& Burkhauser, 1985; Bazzoli, 1985; Chirikos $\&$ Nestel, 1984). When subjective health assessments measure leisure preferences instead of 'true health capacity', estimates of health effects tend to be biased in the direction of poorer reported health driving retirement. More specifically, people who enjoy their work downplay their health problems and work longer, while those who dislike their work may exaggerate health problems and retire sooner.

- Government programmes can give individuals a strong incentive to say that they are unhealthy. Being identified as disabled can be financially rewarding. (The dependence of selfreported health on economic (environmental) characteristics will bias estimates of the impact of economic variables on labour force participation, even if one correctly measures the impact of health itself.) Biased estimates of the impact of health on outcomes will also bias the coefficients on any variable correlated with health. 
- A second influence on self-reports may be health treatment, which in turn may be affected by factors such as an individual's education, income, employment or health insurance status.

- A third concern is that the utilisation of medical care typically increases with income, even though persons with a higher income are generally in better health.

- A fourth concern is that individuals who have health limitations may choose jobs in which their health does not limit their ability to work. This would be expected to bias the estimated effect of 'limits' towards zero.

- A fifth issue is the lack of comparability between respondents (underestimates) and the reporting heterogeneity. Ordered responses on health questions may differ across populations or even across subgroups of a population. This reporting heterogeneity may invalidate group comparisons and measures of health inequality because of a problem called 'state-dependent reporting bias'. ${ }^{1}$ This bias occurs if subgroups of a population systematically use different threshold levels when assessing their health, despite having the same level of 'true' health. These differences may be influenced by age, gender, education, language, personal experience of illness and other factors. It means that different groups use different reference points when they are responding to the same questions. Sen (2002) pointed out that there is a strong need to scrutinise statistics on self-reported illness in a social context by taking note of the levels of education, availability of medical facilities and public information on illness and remedy. The best way to do this is to formalise the problem of heterogeneous reporting behaviour and to formulate tests for its occurrence in the context of subjective health information. A test for differential reporting in ordered response models has been proposed by Lindeboom and van Doorslaer (2003) and allows us to distinguish between cut-point shift and index shift. They find clear evidence of index shifting and cut-point shifting for age and gender, but not for income, education or language.

Longitudinal analysis of the impact of health on retirement will tend to exacerbate the above problems: since one is unlikely to experience a large number of dramatic health-status changes over a short period, many observed changes may be spurious. An additional issue to mention is that the measurement error for indicator variables is more problematic than it is for continuous ones. More detailed health indicators may be less susceptible to measurement and endogeneity problems, since the questions are narrower and more concrete. Including each of the detailed health measures as explanatory variables makes maximum use of the available information on health status.

\subsection{Interpretation}

Difficulties in interpretation may arise for different reasons (Bound et al., 1999):

- There is no obvious way to quantify the marginal effect of changes in health on the outcomes of interest.

- The various detailed measures are collinear to some degree (owing to co-morbidity) and such collinearity would also complicate interpreting the estimated coefficients on particular health measures.

- Even if most health measures only partly describe individual health, they are subject to measurement error. They cover the prevalence of specific conditions but provide little information on severity.

- We are limited by the data. The richest datasets contain data for the American Health and Retirement study (HRS). Most datasets do not cover rich financial or rich health variables, but concentrate on one of these categories. Several surveys - such as the health survey for Finland in 2000 - are cross-sections and only a few have annual waves.

\footnotetext{
${ }^{1}$ Along with the term 'state-dependent reporting bias', this problem has also been called 'scale of reference bias', 'response category cut-point shift', 'reporting heterogeneity' and 'differential item functioning'.
} 


\subsection{Evidence of non-random measurement errors}

There is a lot of evidence that the concerns about non-random measurement errors are justified. Currie and Madrian (1999) sum up the older empirical literature: Bazzoli (1985) finds that the reporting of work limitations prior to retirement had no influence on the probability of retirement before age 65 whereas at the time of retirement it had a strong effect; Sickles and Taubman (1986) find that changes in social security benefits and eligibility for transfers influence self-rated health as well as the probability of withdrawal from the labour force.

The first systematic discussion of the statistical issues involved in the comparison of different health measures was presented in a very influential article by Bound (1991). One possible solution to both the endogeneity and measurement error problems is to instrument measures using objective measures as in Stern (1989). But the procedure cannot be used to examine the relative importance of health and other determinants of the labour supply if the measurement error is correlated with other variables in the model. The analysis of Bound (1991) illustrates this problem using the following example:

$$
\begin{gathered}
L F P=\lambda_{1} \eta+\beta_{1} w+\varepsilon_{1} \\
H=\lambda_{2} \eta+\beta_{2} w+\varepsilon_{2} \\
D=\lambda_{3} v+\varepsilon_{3} \\
w=\lambda_{4} \eta+\varepsilon_{4} \\
\eta=v+u
\end{gathered}
$$

where LFP is labour force participation, $\mathrm{H}$ is a health measure, $\mathrm{D}$ is a more objective measure, $\mathrm{w}$ is the wage, and $\eta$ is true health status. If in Equation (1) H is used as a measure of $\eta$ and D is used as an instrument for $\mathrm{H}$, then we purge $\mathrm{H}$ of dependence on $\varepsilon_{2}$, and $\lambda_{1}$ can be estimated correctly. Nevertheless, $\beta_{1}$ will still be underestimated by an amount $\beta_{2} \lambda_{1}$. The intuition is that we are using the projection of $H$ onto $D$ and $w$ as a proxy for $\eta$, when what we need is the projection of $\eta$ itself on $D$ and w. Note that given another objective measure of health status, one could use D as a proxy for health in Equation (2) and instrument $\mathrm{D}$ using the second measure, thereby producing an unbiased estimate for $\beta_{2}$ that would allow one to calculate $\beta_{1}$.

Anderson and Burkhauser (1985) found an indirect effect of wages on the probability of working through poor health. According to their results, the net effect of wages on labour force participation is similar when either measure of health is used, as long as the dependence of health on wages is accounted for. Kreider (1996) uses an alternative estimator, which is based on the idea that unlike nonworkers, workers who report health limitations have no incentive to systematically over-report such limits.

To summarise, estimates of the impact of health on labour supply may be very sensitive to the measure of health used and to the way in which the estimation procedure takes account of potential measurement error. Although many studies attempt to go beyond ordinary least squares in order to deal with measurement error and the endogeneity of health, it is difficult to find compelling sources of identification. The majority of these studies rely on arbitrary exclusion restrictions, and estimates of some quantities appear to be quite sensitive to the identification assumptions. In a structural approach, identification depends on the validity of the exclusion restrictions.

\section{Empirical evidence on health and retirement}

\subsection{Overview and trends}

General empirical retirement models can be divided into static models, multinomial probit and logit models, duration models (dynamic approach) and structural models (option-value models or dynamic 
programming models) (see also Spartaro, 2002). This section concentrates on important empirical results concerning the relation between the health and labour supply of the elderly. More specifically, different categories of literature can be distinguished: the first category uses subjective health measures and treats them as exogenous variables. The second category treats health as an endogenous variable and uses objective health measures or instruments. The third category uses dynamic programming models. A fourth group overlaps the previous groups and introduces dynamic aspects by analysing the effect of health shocks.

Among the findings, poor health may decrease wages but it may also reduce the effective time endowments and affect the marginal rate of substitution between goods and leisure. Gustman and Steinmeier estimate that the onset of a serious health problem increases the indifference curve by about the same amount as four additional years of age (Gustman \& Steinmeier, 1986). As previously mentioned, the effects of health on labour force participation are theoretically ambiguous, although most research seems to assume that poor health will decrease participation. The estimated effects of health on labour force participation in Europe are summarised in the Appendix in Table A.1. Like Currie and Madrian (1999), we find that there is little consensus on the magnitude of the effects. This may be related to the variation in the health definitions used but also to the fact that the relationship may be socially determined to a high degree. For example, the body mass index - a cumulative measure of health and nutritional status that can be related to mortality risk - covers only certain aspects of a broader health concept. The size of the estimated effect may also be sensitive to age, cohort, gender and the family circumstances of the sample individuals. Costa (1996) finds that health is now a less-important determinant of retirement than it was in the past. This finding is in line with health having a bigger influence on wages in developing countries than in developed countries.

For men, trends in objective measures of health - such as mortality - do not seem to match well with trends in labour force participation (Parsons, 1982). This finding could be explained by the introduction and the expansion of social insurance programmes and their mediation in the relationship between health and participation. Further, this may explain why those in poor health are more likely to withdraw from the labour market than they were previously. (That being said, trends in labour force participation may be in line with health trends if one considers rising mental health problems over time - see Ettner et al., 1997). The relevance of changing institutions implies that estimates of the link between participation and health can be very sensitive to samples, timeframes and omitted variables biases of different types.

The literature that studies the relation between health and labour force participation can be desegregated into different overlapping approaches. These include: 1) treating health as exogenous; 2) treating health as endogenous; 3 ) taking into account dynamic aspects by modelling health shocks; and 4) using dynamic programming models.

\subsection{Health as an exogenous variable}

The first group of literature uses health status or self-reported work limitations and concluded that self-reported poor health seemed to be a major determinant of labour force participation when health was treated as an exogenous variable in an OLS model.

$$
y_{i t}=\eta_{i t} \lambda+X_{i t} \beta+\varepsilon_{i t}
$$

\subsection{Health as an endogenous variable}

A second group of earlier studies compare subjective health measures with more objective ones. ${ }^{2}$ Roughly, it would be expected that the impact of health on retirement is overestimated in the case of

\footnotetext{
${ }^{2}$ See for example Chirikos \& Nestel (1984), Anderson \& Burkhauser (1985) and Bazzoli (1985).
} 
systematic reporting errors and underestimated in the case of substantial endogeneity. The literature concludes that measures overstate the effect of health and understate the effect of financial incentives on labour force participation. It was therefore appropriate to search for unbiased measures. Soon afterwards objective measures were used and their results were interpreted as being superior to those where subjective health variables were used.

A third group of studies tries to deal explicitly with the endogeneity and measurement error issues and instrument measures using objective measures. Examples are Stern (1989) and Kreider (1996). Most of these studies concentrate explicitly on the labour force participation decisions of the elderly rather than those of younger workers.

Bound (1991) uses the Retirement History Survey to illustrate the impact that using the different health measures has on the estimated effects of both health and financial incentives on retirement. $\mathrm{He}$ presents a statistical model that is unidentified. To be able to identify it he uses external information. A general conclusion is that those with health problems exaggerate the impact of poor health on work potential. A second finding that supports the justification hypothesis is that retirees' self-assessed health was worse after retirement than before. Bound states that "the search for 'objective' or exogenous indicators of health status may have been a bit misplaced" and concludes that using selfreported health may be better than more objective measures. The reason is that two different biases may cancel each other out as the self-reported health measurement error in health biases the coefficient on health downwards, whereas the endogeneity of health may bias the estimated effects upwards. To the extent that more objective measures of health are not very accurate measures of 'work capacity', they are biased towards zero only.

Bound et al. (1999) use a latent model to construct a time-varying individual health stock to strip the health term in the labour force participation equation of possible endogeneity of response (see also section 4.5 on health shocks for results). Using health status, $h_{i t}$ as a proxy for $\eta_{i t}$ directly will be biased if the reporting error term in Equation (8) is correlated with terms in the labour force participation equation. But simply entering the $z_{\text {it }}$ vector in Equation (7) directly into a labour force participation equation will likely induce errors in variables biases, because more specific health factors, even if accurately reported, may not predict current capacity to work. Bound et al. (1999) argue that using the latent variable model in Equation (9) is a standard measure of dealing with these problems. They use a proxy with error to instrument an endogenous and an error-ridden variable such as $h^{*}$. Assume that an individual's $i$ health at time $t$ is determined by a linear combination of exogenous personal characteristics $X_{\text {it }}$ (such as age or education), a vector of detailed personal health indicators $z_{i t}$ (such as functional limitations) and unobservable $v_{t}$ uncorrelated with $X_{i t}$ and $z_{i t}$. The impact of these characteristics is allowed to vary over time. This (unobserved) health state is denoted as $\eta_{\mathrm{it}}$ :

$$
\eta_{i t}=X_{i t} \beta+z_{i t} \gamma_{t}+v_{i t}
$$

Although this health state is not observed, a health status can be observed as a categorical variable with five states: very good, good, fair, poor and very poor. Denote this categorical variable as $h_{i t}$. The latent counterpart to $h_{i t}$, which is denoted by $h^{*}$ it is a simple function of $h_{i t}$ and a term reflecting reporting error:

$$
h^{*}{ }_{i t}=\eta_{i t}+\varepsilon_{i t}
$$

Crucially, they assume that $\varepsilon_{i t}$ is uncorrelated with $v_{i t}$. Yet is possible that the reporting error is correlated with the state in which the individual is located. 
By using this instrumental variable type procedure, they assume that the errors are uncorrelated with those arising when reporting specific health limitations. They proceed with the following equation:

$$
\begin{aligned}
& h^{*}{ }_{i t}=X_{i t} \beta+z_{i t} \gamma_{t}+\left[v_{i t}+\varepsilon_{i t}\right] \\
& h^{*}{ }_{i t}=X_{i t} \beta+z_{i t} \gamma_{t}+u_{i t}
\end{aligned}
$$

Assuming that $\mathrm{u}_{\mathrm{it}}$ is normally distributed, Equation (9) can thus be estimated as an ordered probit.

$$
\begin{aligned}
& y_{i t}^{*}=\eta_{i t} \lambda+X_{i t} \beta+\varepsilon_{i t} \\
& y_{i t}=\left\{\begin{array}{lll}
1 & \text { if } y_{i}^{*}>0 \\
0 & \text { if } \quad y_{i}^{*} \leq 0
\end{array}\right.
\end{aligned}
$$

Several studies suggest that individual fixed effects are important in modelling retirement (Meghir \& Whitehouse, 1997; Blundell et al., 2002). Standard probit or logit identifies effects of all individuals, including those who are active or inactive over the whole period. Using fixed effects has the advantage that one can focus on persons who transition through various states and establish a link between changing health status and retirement, as opposed to simply underlying in(activity). An alternative approach includes the person's specific fixed (or random) effects $\alpha_{i}$ in Equation (13) in order to capture unobserved characteristics that could be correlated with both health and labour force participation:

$$
y_{i t}^{*}=\alpha_{i}+\eta_{i t} \lambda+X_{i t} \beta+\varepsilon_{i t}
$$

Sickles and Taubman (1986) estimate a model of health and retirement in which health affects retirement, but not vice-versa. The random effects are assumed to be uncorrelated across retirement and health equations. The estimation technique is complex, involving a 10-dimensional integration of the multivariate normal density function. The authors assume the following arbitrary exclusion restrictions: the age dummy and the "gain for postponing retirement" can be excluded from the health equation while the social security insurance eligibility and the social security benefits are excluded from the retirement equation. The authors find that poor health does indeed hasten retirement although the interpretation of the magnitude of the effect is not clear due to the definition of their health variable.

Blau et al. (1997) take this approach further by estimating models that include semi-parametric random effects in order to account for unobserved heterogeneity that affects health and also employment at the time of the initial survey and attrition from the survey. These variables are assumed to all depend on the same set of random effects. The complete model is identified using non-linearities in these equations, as well as the fact that several variables assumed to affect health, initial employment and attrition are excluded from the fourth equation for employment transitions. The inclusion of the random effects reduced the estimated effects of the health measures, although they remain important.

Dwyer and Mitchell (1999) explain the expected age of retirement ${ }^{3}$ - an unusual dependent variable in the retirement literature ${ }^{4}$ - by an array of subjective and objective health measures. Their approach belongs to the category of literature that seeks to circumvent endogeneity problems by instrumenting

\footnotetext{
${ }^{3}$ What is meant by the expected age in statistical terms is, however, not clear (see McGarry, 2004). For those already out of the labour force actual retirement age is used, which again causes potential bias.

${ }^{4}$ This variable is constructed by using the planned age of full retirement ( $69 \%$ of the sample), while the other missing $31 \%$ of the sample uses the expected age to begin receiving social security or pension benefits $(19 \%$ of the sample) or the conditional (based on age and experience) actual retirement age (12\% of the sample).
} 
subjective endogenous health measures by more objective health measures or by other instruments. They find little evidence of measurement error or justification hypothesis. Poor health is associated with earlier retirement plans. Functional limitations result in earlier expected retirement by one to two years. Self-rated health measures are not endogenously determined with labour supply and seem not to be correlated with compensation variables.

Some papers compare the effects of financial variables and subjective health status on retirement. Bound (1991), Dwyer and Mitchell (1999) and McGarry (2004) find that the effects of health variables are substantially stronger than the financial ones. It is, however, important to note that the comparability of the results is mostly reduced because of the difference in samples, statistical methods and dependent variables. Instead of using a 0/1 variable indicating retirement, McGarry (2004) uses a new measure of labour force attachment, the subjective probability of continuing full-time work until the age of 62. This variable can be viewed as a measure of the strength of labour force attachment. The use of this variable allows for concentrating on employed persons only and so avoids the potential biases from the miss-reporting of health among those already retired, as well as any biases introduced by a relationship wherein changes in labour force participation induce changes in health. But this approach does not avoid biases introduced by the unobserved individual effects that are correlated with the regressors. Because the expected probability of continued work is only observed for persons in the labour force, a sample selection problem arises. The author first analyses a cross-section and then looks at the changes over time. Thus different measures of health are used. Instead of mortality the author uses the probability with which the respondent expects to live to age 85. Along with subjective health measures, the alternative health measures used are: lagged health, diseases, activity limitations and multiple measures of health. The most important results of McGarry's analysis can be summarised in four points:

1) Despite the lack of justification bias, poor health has a large and significant effect on labour market attachment.

2) Health status continues to be significant when alternative measures of health are also included into the specification. Replacing health with alternative health measures to circumvent potential biases may therefore introduce a new bias due to omitted variable problems.

3) Most strikingly and in contrast to most previous results, the included measure of health does not affect the estimated effects of income and wealth. This is in line with results of Dwyer and Mitchell (1999). The author places her results and those of the previous contrasting studies in a historical perspective and explains them by a change in attitude towards early retirement.

4) Changes in retirement plans are strongly correlated with changes in health and only weakly related to changes in financial variables.

Kerkhofs et al. (1999) use a competing risk model for employment duration to specify their retirement model empirically. This model allows them to deal with the censored observations and time-varying regressors (age, health, eligibility conditions and benefit replacement rates) associated with alternative retirement dates. Their approach has several interesting aspects. First, it concentrates on three alternative exit routes for the Netherlands: early retirement (ER), disability insurance (DI) and unemployment insurance (UI). Second, the estimated retirement model uses different health measures and is able to assess the effect of reporting errors and the endogeneity of health to retirement. The authors find that endogeneity is important in the case of ER and UI and that reporting errors are very important in the case of DI. The authors conclude that health is dominant in explaining transitions into DI and UI schemes. Financial incentives are the most important factor in the decision to apply for an ER scheme. Their comparison of different health instruments - which they obtain from estimating a dynamic health equation - shows that it is crucial to restrict the choice of control variables to the ones that are exogenous to the potentially simultaneous career and health-related household decisions. The estimated effects of the financial variables are robust to the use of the different health variables and their different measurement problems. 
The reduced-form model of Lindeboom and Kerkhofs (2002) elaborates two equations of labour supply and health reporting from Bound et al. (1999), but adds a third equation for health production. It is an important European paper that circumvents endogeneity problems by integrating work decisions, health production and health-reporting mechanisms. The authors estimate their model on Dutch longitudinal data using simulated maximum-likelihood techniques. Three stochastically related parts are estimated: 1) a model for work where financial incentives and health can affect retirement behaviour; 2) a health production model where current health levels can be affected by past labour market outcomes; and 3) a model for health reporting behaviour that translates the observed subjective health index into a health measure that is free of reporting errors. The index is used in the model for work. This methodology enables them to assess the causal effects of health and financial incentives on work, the effect of work history on general health and work-related health and the extent to which subjective health measures are biased. The analysis finds strong effects of health on retirement. The use of subjective measures in labour supply models delivers biased results. This notably holds for disability insurance recipients. A very interesting result is that their health production model reveals that increased work efforts eventually lead to a deterioration of health. This finding suggests that pension and social security reforms that aim at increasing the labour force participation of the elderly may have an adverse effect on the distribution of health among the elderly, with obvious health-care consumption and other effects.

\subsection{Dynamic programming models}

Another group of health and retirement models calculate a solution to a dynamic programming model. Berkovic and Stern (1991) estimate a model of retirement that includes not only unobserved individual effects, but also unobserved job-specific match effects. Their model focuses on dynamics by comparing a version in which individuals consider the value of future income flows - calculated as the solution to a dynamic programming model - and a static model in which these flows are ignored. Health is coded as ' 0 ' if there are no work limitations, as ' 2 ' 'if there are limitations and as ' 1 ' if the health status is uncertain. The model requires future health to be simulated, which is done by assuming that individuals have a fixed probability of becoming ill, and once they become sick they stay that way. Individuals are assumed to have no uncertainty about their future health, an important limitation of the model. The model is solved using a Simulated Method of Moments technique. The results suggest that poorer health increases the value of retirement relative to either part-time or full-time employment. The dynamic model is found to provide a better fit for the data than a static alternative model, suggesting that it is important to take beliefs about future health into account.

Stern (1996) asks whether health influences labour force participation primarily through supply or through demand factors. In the semi-parametric model, 'supply' can be seen as a participation decision while demand conditions are captured by the wage conditional on participation. The estimates indicate that health limitations on the ability to work have larger effects on labour supply than on labour demand. A potential problem may be that the health measure may be a better measure of a person's attitude to work or of the available alternatives than of their productivity.

\subsection{Health shocks}

Recent research stresses the importance of taking into account the dynamic aspects of health and uses health shocks (changes in health) instead of health levels. Health shocks have been divided into three categories by McClellan (1998): 1) acute health events, 2) the onset of a new chronic disease and 3) accidental injuries or falls. Anderson et al. (1986) and Bound et al. (1999) suggest that changes in labour market status should be associated with shocks to the individual's underlying health status. Bound et al. (1999) construct a latent health stock or index of health for each individual as a function of personal characteristics and health indicators. They use this constructed variable to instrument health in a panel data model and analyse the relationship between time variation in health and changes in work status. They analyse the relationship between the health and labour force transitions of older workers based on the first three waves of the HRS (1992-96). Their approach has two interesting characteristics: it is 
indeed a (two lags) dynamic health approach modelling health shocks and it does not concentrate solely on labour force exit (0-1 dummy), but considers three different transitions out of employment - labour force exit, job change and application for disability insurance. In the first stage they estimate an ordered probit model for health using self-reported health status and a functional limitations variable. In a second stage they use a multinomial probit to examine the effect of health on labour force behaviour using the estimates of the health model. Their results confirm that not only poor health but also a decline in health is an important determinant of the labour force patterns for older men and women. Poor health leads many older workers to withdraw from the labour force. Among persons in poor health more than half of those who exit the labour force apply for DI. Among those who keep working, many change jobs within several years of the onset of poor health, suggesting that changing jobs is an important way for older workers adapt to enable continued labour force participation. The results confirm the value of modelling alternative labour force outcomes beyond the binary outcome of labour force withdrawal. Their results also suggest that the relationship between health and labour force behaviour is dynamic, although no precise attempt is made at effect estimation. Overall, the earlier a health shock occurs in their models, the less likely it is to lead to labour force exit.

The same two-step approach of Bound et al. (1999) is also used by Disney et al. (2003). The authors examine the role of ill health in retirement decisions in Britain using fixed-effect estimators. They show that adverse individual health shocks are an important predictor of individual retirement behaviour. Disney et al. (2003) argue that modelling health shocks eliminates any person-specific association between characteristics and labour market outcomes, while using time-varying health and personal characteristics as a proxy for health status should ameliorate any reporting bias in the former. They find no convincing evidence of the importance of the partners' health for the individual retirement decision and no significant differences between men and women based on the inclusion of an additional interaction of health stock with a gender dummy. (The approach of Coile [2003] using health shocks for both spouses is described in section 5.2 on the effect of the health of family members on participation.) Finally, Disney et al. find some evidence of asymmetry in the sense that worsening health has a bigger impact on moving into retirement than an improving health has on coming out of retirement.

\section{Gender differences and household dynamics}

\subsection{Gender differences in the effects of health on labour market participation}

Relatively few studies examine both men and women in the same framework. Loprest et al. (1995) observe that the effects of disabilities on labour force participation are greater for men and single women than for married women. Ettner (1997) finds evidence that being out of the labour force is less stigmatising for women than for men, so there is less reporting bias among women. Analysing gender differences in retirement behaviour is certainly a field for further exploration as participation patterns of both men and women have been changing. It may also be optimal to take into account those differences in shaping the future pension systems.

\subsection{Health of other family members and labour market participation}

Although most literature on health and labour force participation focuses on the individual, there is a trend towards taking into account the health of other family members such as children, parents and especially spouses. A recent development in the modelling of retirement decisions concerns the 'couple approach'. Using a couple approach can be supported by the fact that women's retirement decisions are not yet well understood and by the possibility of spousal spillover effects on retirement incentives. The traditional approach to analysing the labour force behaviour of married couples is based on the family labour supply model. Behaviour is determined by the maximisation of a single utility function subject to a family budget constraint in which income is pooled and the allocation of consumption between the spouses is not modelled. A second approach can be a bargaining model based on cooperative game theory. The growing empirical literature on couples' retirement consists of papers that estimate structural 
models of family labour supply and reduced-form models that explore the cross-effects of one spouse's characteristics on the other spouse's retirement decision. These papers typically find that the complementarity of leisure is much more important in explaining joint retirement than either a correlation in preferences or shared household finances. Having a retired spouse increases the probability of retirement. Neither of the sets of studies controls for health for the most part nor do so using health status, subjecting the resulting estimates of the effect of health to the critique that these are biased. Some couple-approach studies that do pay attention to health are summarised below.

Favreault \& Johnson (2001) analyse the retirement decisions of married couples in the US and how they interact with spousal health and employment using the first three waves (1992-96) of the HRS. For each gender they estimate a multivariate model of the retirement decisions. Alongside the retirement decision, the spousal work status is treated endogenously as it may be determined jointly with the individual's own retirement decision. They find that the employment and health status of the spouse appear to have important effects on the retirement decisions of married women and men. When the spouse does not have health problems, women and men were more likely to retire if the spouse was not employed than if the spouse was still at work. Yet when the spouse had health problems, nonemployment of the spouse generally reduced retirement rates for both men and women. The effects were generally stronger when the spouse was not eligible for social security retirement benefits (younger than 62). No evidence was found that the demands of spousal care-giving affect retirement decisions. These findings underline the importance of marriage in providing insurance for those who become disabled. The authors conclude that because of the correlation between unobservable factors, it is important that the labour supply decisions of married persons are estimated jointly.

One of the first European couple-approach papers analyses the labour force transitions of older married couples in West Germany (Blau \& Riphahn, 1999). A measure of subjective health satisfaction and the presence and the degree of an officially recognised handicap did not turn out to have an impact on the transition rates. In their final specification the authors only included a dummy for chronic disease; just a few point estimates of that variable were significant. They found that individuals with a chronic health condition are less likely to stay employed and more likely to exit the labour force. Wives are less likely to exit the labour force and more likely to enter the labour force if the husband has a chronic condition and is still working and are in contrast more likely to exit and less likely to enter if the husband has left the labour force. The same pattern does not hold for men (evidence of asymmetries). Husbands are less likely to stop employment and less likely to re-enter employment if the wife has a health condition, a response that is independent of the wife's labour force status.

The important couple-approach analysis of Coile (2003) uses a broad range of health variables for the US and concentrates on health events. The study is based on the first five waves (1992-2000) of the HRS. The analysis estimates reduced-form models that measure the effect of each spouse's health events on the other spouse's labour supply (hours and participation). It is the first paper that combines a broad range of health variables and a couple approach. In doing so it links two important strands of retirement literature - the large body of literature on health and retirement and the small but growing literature modelling retirement in a family context. Coile examines the three types of health shocks of McClellan (1998) (as previously discussed). Other health variables used are the functional impairment index (the index is based on whether the individual reports any difficulty in performing a series of 17 activities of daily living (ADLs). The index ranges from 0 (difficulties in no activities) to 1 (difficulty in all 17 activities) and the survival probabilities. The study exploits exogenous shocks to health between waves of the survey to explore the effect of health on one's own and the spouse's labour supply. The two dependent variables used are the change in hours and the exit from the labour force (dummy). The spouse's response to health shocks has important financial implications for the family but can be crowded out by the available government benefits. The major findings of the paper include that health shocks have an important effect on one's own retirement. In the sample as a whole health shocks have no significant effect on the spouse's retirement either for men or women. This aggregate non-response may be explained by offsetting responses from different groups. This suggests that behaviour is affected by the provision of health insurance, the presence of other potential caregivers, 
the importance of the lost income and the availability of disability benefits. These offsetting responses are more often found for men, suggesting that men may respond more to their spouses' health shocks than women. Finally there is evidence of a substantial crowding-out of spousal labour supply by disability insurance benefits.

\section{Conclusions}

Health plays an important role in retirement models although there is no consensus about the magnitude of the effects or about the size relative to the effects of other variables. Estimates of the impact of health on labour supply may be very sensitive to the measure of health used and to the way in which the estimation procedure takes account of potential measurement errors. Although many studies attempt to go beyond ordinary least squares in order to deal with measurement errors and the endogeneity of health, it is difficult to find compelling sources of identification. The majority of these studies rely on arbitrary exclusion restrictions and estimates of some quantities appear to be quite sensitive to the identification assumptions. Most complete models take into account correlations between participation, health reporting and health production. They also take into account different available health measures to test for robustness.

Different trends in the literature have appeared as new data and new estimation techniques have become available. One trend relates to the use of very detailed health data in new databases. A second trend involves the exploration of the nature of panel data and introduces dynamics into the models by modelling participation transitions and health shocks. A third trend in research is where it takes into account different, institutionally defined pathways towards retirement as health can play a "pathdependent' role. A fourth trend includes studying health effects of both spouses in the explanation of an individual's participation in the labour force. A final, broader trend concerns the use of dynamic programming techniques in retirement models. Research that uses European data is still limited but rapidly expanding. The future development of the SHARE database project (see Appendix C) will certainly intensify analysis and expand understanding of the complex relationship between health and the labour force participation of elderly Europeans.

Thus the current conclusion of the literature is that health has an important effect on retirement, but there is no perfect method for estimating the magnitude of the effect. Aiming at unbiased effects is, however, crucial, as an understanding of the unbiased effects of health and financial incentives on labour force participation is essential for simulations and solid economic policy advice. 


\section{Bibliography}

Anderson, K.H. and R.V. Burkhauser (1984), "The Importance of the Measure of Health in Empirical Estimates of the Labour Supply of Older Men", Economic Letters, Vol. 16, pp. 375-80.

(1985), "The retirement-health nexus: A new measure of an old puzzle", Journal of Human Resources, Vol. 20, pp. 315-30.

Anderson K.H., J.S. Butler and R.V. Burkhauser (1986), "Testing the Relationship between Work and Health: A Bivariate Hazard Model”, Economic Letters, Vol. 20, pp. 383-86.

Bazzoli, G.J. (1985), "The early retirement decision: New empirical evidence on the influence of health", Journal of Human Resources, Vol. 20, pp. 214-34.

Becker, G.S. (1964), Human Capital, New York: Columbia University Press.

Berkovec, J. and S. Stern (1991), "Job Exit Behavior of Older Men”, Econometrica, Vol. 59, No. 1, pp. 189-210.

Blau, D.M., D.B. Gilleskie and C. Slusher (1997), "The effects of health on employment transitions of older men", unpublished paper, University of North Carolina, Chapel Hill.

Blau, D.M and R.T. Riphahn (1999), "Labour Force Transitions of Older Married Couples in Germany", Labour Economics, Vol. 6, pp. 229-52.

Blundell, R., C. Meghir and S. Smith (2002), "Pension incentives and the pattern of early retirement", Economic Journal, Vol. 112, March, C 153-170.

Booth, A.L. (ed.) (1999), "The health, wealth and work of older people", paper from the Conference on the Economics of Aging, International Health and Retirement on 7-8 August 1997 in Amsterdam, Labour Economics, Vol. 6, No. 2, June.

Börsch-Supan, A. (2000), Data and Research on Retirement in Germany, Discussion Paper No. 00-20, Mannheim Research Institute for the Economics of Aging, Universität Mannheim, p. 18.

Börsch-Supan, A., S. Kohnz and R. Schnabel (2003), "Micro Modelling of Retirement Choices in Germany" in J. Gruber and D. Wise (eds), Incentive Effects of Public Pension Systems, University of Chicago Press: Chicago (in press).

Bound, J. (1991), "Self-Reported versus Objective Measures of Health in Retirement Models", The Journal of Human Resources, Vol. 26, No. 1, pp. 106-38.

Bound, J. and R. Burkhauser (1999), "Economic analysis of transfer programs targeted at people with disabilities" in O. Aschfelter and D. Card (eds), Handbook of Labour Economics, Vol. 3C, Amsterdam: Elsevier Science Publishers BV, pp. 3417-528.

Bound, J., M. Schoenbaum, T.R. Stinebrickner and T. Waidmann (1999), "The dynamic effects of health on the labour force transitions of older workers", Labour Economics, Vol. 6, pp. 179-202.

Chirikos, T.N. and G. Nestel (1984), "Economic determinants and consequences of self-reported work disability", Journal of Health Economics, Vol. 3, pp. 117-36.

Coile, C. (2003), Health Shocks and Couples’ Labor Supply Decisions, Working Paper No. 2003-08, Centre for Retirement Research at Boston College, May.

Coile, C. and J. Gruber (2000), Social Security and Retirement, NBER Working Paper No. 7830, NBER, Cambridge, MA.

Costa, D.L. (1996), "Health and Labour Force Participation of Older Men, 1900-1991", The Journal of Economic History, Vol. 56, No. 1, pp. 62-89. 
Currie, J. and B.C. Madrian (1999), "Health, Health Insurance and the Labour Market" in O.C. Ashenfelter and D. Card (eds), Handbook of Labour Economics, Volume 3C, Amsterdam: Elsevier Science Publishers BV, pp. 3309-416.

Disney, R., C. Emmerson and M. Wakefield (2003), Ill Health and Retirement in Britain: A Panel DataBased Analysis, Working Paper No. 03/02, Institute for Fiscal Studies, London, p. 28.

Dwyer, D.S. and O.S. Mitchell (1999), "Health Problems as Determinants of Retirement: Are Self-Rated Measures Endogenous?", Journal of Health Economics, Vol. 18, pp. 173-93.

Ettner, S. (1997), "Is working good for you? Evidence on the endogeneity of mental and physical health to female employment", unpublished paper, Harvard School of Public Health, Boston.

Ettner S., R. Frank and R. Kessler (1997), The impact of psychiatric disorders on labor market outcomes, NBER Working Paper No. 5989, NBER, Cambridge, MA.

Griliches, Z. (1977), "Estimating the returns of schooling: Some econometric problems", Econometrica, Vol. 45, pp. 1-22.

Grossman, M. (1972), "On the concept of health capital and the demand for health", Journal of Political Economy, Vol. 80, pp. 223-55.

Gustman, A.L. and T.L. Steinmeier (1986), “A structural retirement model”, Econometrica, Vol. 54, pp. 555-84.

Hakola, T. (2002a), Economic Incentives and Labour Market Transitions of the Aged Finnish Workforce, VATT Research Reports No. 89, Government Institute for Economic Research, Helsinki, p. 193.

- (2002b), Alternative Approaches to Model Withdrawals from the Labour Market - A Literature Review, Working Paper No. 2003:4, Department of Economics, Uppsala University, p. 39.

Favreault, M.M. and R.W. Johnson (2001), Retiring Together or Retiring Alone: The Impact of Spousal Employment and Disability on Retirement Decisions, Working Paper No. 2001-01, Centre for Retirement Research at Boston College, March.

Jiménez-Martín, S., J.M. Labeaga and M. Martínez Granado (1999), Health Status and Retirement Decisions for Older European Couples, Working Paper No. 1999-01, IRISS, Luxembourg, p. 34.

Kerkhofs, M., M. Lindeboom and J. Theeuws (1999), "Retirement, Financial Incentives and Health", Labour Economics, Vol. 6, pp. 203-27.

Kreider, B. (1996), "Latent work on disability and reporting bias", unpublished paper, University of Virginia, Charlottesville.

Lazear, E.P. (1986), "Retirement from the labour force" in O.C. Ashenfelter and R. Layard (eds), Handbook of Labour Economics, Volume 1, Amsterdam: Elsevier Science Publishers BV, pp. 30555.

Lechner, M. and R. Vazquez-Alvarez (2003), "The Effect of Health Status on Labour Market Outcomes: A Case Study of Germany with Evidence from Matching", preliminary draft, p. 42.

Leung, S.F. and C.T. Wong (2002), "Health Status and Labor Supply: Interrelationship and Determinants", mimeo, Hong Kong University of Science and Technology, version dated 28 May 2002.

Lindeboom, M. and M. Kerkhofs (2002), Health and Work of the Elderly, Subjective Health Measures, Reporting Errors and the Endogenous Relationship between Health and Work, Discussion Paper No. 457, Institute for the Study of Labor (IZA), Bonn, March, p. 39.

Lindeboom, M. and E. van Doorslaer (2003), Cut-Point Shift and Index Shift in Self-Reported Health, Discussion Paper No. TI 2003-042/3, Tinbergen Institute, Amsterdam, p. 24.

Loprest, P., K. Rupp and S. Sandell (1995), "Gender, disabilities and employment in the health and retirement study", Journal of Human Resources, Vol. 30, pp. 293-318. 
Lumsdaine, R.L. and O.S. Mitchell (1999), "New Developments in the Economic Analysis of Retirement" in O.C. Ashenfelter and D. Card (eds), Handbook of Labour Economics, Volume 3C, Amsterdam: Elsevier Science Publishers BV, pp. 3261-307.

Mastrogiacomo, M., R. Alessie and M. Lindeboom (2002), Retirement Behaviour of Dutch Elderly Households: Diversity in Retirement Patterns across Different Household Types, Discussion Paper No. TI2002-073/03, Tinbergen Institute, Amsterdam, 24 May, p. 35.

McClellan, M. (1998), "Health Events, Health Insurance, and Labour Supply: Evidence from the Health and Retirement Survey" in D.A. Wise (ed.), Frontiers in the Economics of Aging, Chicago: University of Chicago Press.

McGarry, K. (2004), "Health and Retirement: Do Changes in Health Affect Retirement Expectations?", Journal of Human Resources, Vol. 39, No. 4, pp. 624-48.

Meghir, C. and E. Whitehouse (1997), "Labour market transitions and the retirement of men in the UK", Journal of Econometrics, Vol. 79, pp. 327-54.

Parsons, D.O. (1982), "The male labor force participation decision: Health, reported health and economic incentives", Economica, Vol. 49, pp. 81-91.

Riphahn, R.T. (1995), Disability Retirement among German Men in the 1980s, Münchner Wirtschaftswissenschaftliche Beiträge, Nr. 95-20, Ludwig Maximilians Universität München.

Sammartino, F. (1987), “The Effect of Health on Retirement”, Social Security Bulletin, No. 50, February, pp. 31-47.

Sen, A. (2002), "Health: Perception versus observation", British Medical Journal, Vol. 324, pp. 660-61.

Sickles, R.C. and P. Taubman (1986), "An Analysis of the Health and Retirement Status of the Elderly", Econometrica, Vol. 54, No. 6, pp. 1339-56.

Spartaro, L. (2002), New Tools in Micromodeling Retirement Decisions: Overview and Applications to the Italian Case, CeRP Working Paper No. 28/02, CeRP, Moncalieri, p. 41.

Stern, S. (1989), "Measuring the effect of disability on labor force participation", Journal of Human Resources, Vol. 24, pp. 361-95.

(1996), "Semi-parametric estimates of the supply and demand effects of disability on labor force participation", Journal of Econometrics, Vol. 71, pp. 49-70.

Stock, J.H. and D.A. Wise (1990), "Pensions, the Option Value of Work and Retirement", Econometrica, Vol. 58, pp. 1151-80.

Strauss, J. and D. Thomas (1998), "Health, nutrition and economic development", Journal of Economic Literature, Vol. 36, pp. 766-817.

Wooldridge, J.M. (2002), Econometric Analysis of Cross-Section and Panel Data, Cambridge, MA: MIT Press. 


\section{Appendix A \\ Summaries of Results}

Table A.1 Results for European countries using an individual approach

\begin{tabular}{|c|c|c|c|}
\hline $\begin{array}{c}\text { Author, dataset and } \\
\text { sample }\end{array}$ & $\begin{array}{c}\text { Labour force } \\
\text { participation (LFP) and } \\
\text { health measures }\end{array}$ & $\begin{array}{l}\text { Estimation } \\
\text { technique }\end{array}$ & Results \\
\hline $\begin{array}{l}\text { Author: Riphahn (1995) } \\
\text { Dataset: Germany, GSOEP, } \\
\text { eight waves (1984-91) } \\
\text { Sample: men, aged 46-62 } \\
\text { no civil servants, miners or } \\
\text { self-employed persons }\end{array}$ & $\begin{array}{l}\text { LFP: three states - working, } \\
\text { disability retirement, non- } \\
\text { employment } \\
\text { Health: } \\
\text { - health satisfaction } \\
\text { indicator } \\
\text { - official degree of } \\
\text { handicap indicator }\end{array}$ & $\begin{array}{l}\text { Approximation of a } \\
\text { dynamic programming } \\
\text { model } \\
\text { - Joint estimation of two } \\
\text { discrete times, competing } \\
\text { risks hazard models with a } \\
\text { set of four initial } \\
\text { conditions equations, one } \\
\text { wage equation and one } \\
\text { health equation } \\
\text { - Control for permanent and } \\
\text { time-varying unobserved } \\
\text { heterogeneity }\end{array}$ & $\begin{array}{l}\text { Poor-health coefficient: } \\
-0.28928 \text { (exit from work) } \\
-0.37206 \text { (exit from non- } \\
\text { employment) } \\
\text { Poor health status strongly } \\
\text { increases the risk of leaving } \\
\text { the states of working and } \\
\text { non-employment for } \\
\text { disability retirement } \\
\text { Effect of poor health is much } \\
\text { stronger than that of benefits } \\
\text { Estimates are fairly } \\
\text { insensitive to the particular } \\
\text { measure of health }\end{array}$ \\
\hline $\begin{array}{l}\text { Authors: Kerkhofs et al. } \\
\text { (1999) } \\
\text { Dataset: The Netherlands, } \\
\text { CERRA, first two waves } \\
\text { (1993 and 1995) } \\
\text { Sample: men and women, } \\
\text { individuals employed in } \\
1991\end{array}$ & $\begin{array}{l}\text { LFP: hazard rate out of } \\
\text { work } \\
\text { Health: self- reported } \\
\text { subjective health measure } \\
\text { of health limitation (first } \\
\text { wave) } \\
\text { - objective HSCL } \\
\text { - health instruments derived } \\
\text { from a panel data model of } \\
\text { health dynamics }\end{array}$ & $\begin{array}{l}\text { - Competing risks (three } \\
\text { alternative retirement } \\
\text { routes) model for } \\
\text { employment duration } \\
\text { - Dynamic fixed effects } \\
\text { model for health } \\
\text { - Maximum likelihood } \\
\text { - IV }\end{array}$ & $\begin{array}{l}\text { Health matters } \\
\text { (Coeff.: } 3.11 \text { - disability } \\
\text { insurance) } \\
\text { (Coeff.: } 0.28 \text { - early } \\
\text { retirement) } \\
\text { (Coeff.: } 0.21 \text {-unemployment } \\
\text { insurance) } \\
\text { - degree of health effect } \\
\text { depends on the health } \\
\text { measure used } \\
\text { - subjective health } \\
\text { measures overstate the } \\
\text { effect of health } \\
\text { - endogeneity of health } \\
\text { suppresses the health } \\
\text { effect } \\
\text { - incentive effects are } \\
\text { relatively insensitive to } \\
\text { alternative specifications } \\
\text { for health }\end{array}$ \\
\hline $\begin{array}{l}\text { Authors: Disney et al. } \\
\text { (2003) } \\
\text { Dataset: Britain, BHP, eight } \\
\text { waves (1991-98) } \\
\text { Sample: men and women, } \\
\text { active and inactive, aged } 50 \\
\text { to } 64 \text { in } 1991 \text { who reached } \\
57 \text { to } 71 \text { in } 1998 \text {. Sample of } \\
1,712 \text { individuals in } 1991 \text {, } \\
\text { reduced to } 1,253 \text { by } 1998 \text {. }\end{array}$ & $\begin{array}{l}\text { LFP: labour force } \\
\text { participation (employed and } \\
\text { self-employed) } \\
\text { Health: deviations of } \\
\text { individual health stock } \\
\text { measure from average at } t\end{array}$ & $\begin{array}{l}\text { - Reduced-form model of } \\
\text { retirement } \\
\text { - Two-stage method: } \\
\text { 1) ordered probit } \\
\text { estimator for health } \\
\text { stock } \\
\text { 2) standard logit, linear } \\
\text { and non-linear fixed } \\
\text { effects logit } \\
\text { estimators for LFP }\end{array}$ & $\begin{array}{l}\text { Relative (good) health status } \\
\text { (underlying health stock) is } \\
\text { strongly and positively } \\
\text { associated with economic } \\
\text { activity } \\
\text { Coefficients of health stock: } \\
0.279^{* * *} \text { (fixed effects logit), } \\
0.752^{* * *} \text { (logit), } 0.035^{* * *} \\
\text { (linear fixed effects) }\end{array}$ \\
\hline
\end{tabular}




\begin{tabular}{|c|c|c|c|}
\hline $\begin{array}{l}\text { Authors: Lindeboom et al. } \\
\text { (2002) } \\
\text { Dataset: The Netherlands, } \\
\text { CERRA, first two waves - } \\
\text { 1993-95 } \\
\text { Sample: men and women, } \\
\text { head of household aged } 43 \\
\text { to } 63 \text {. Sample of } 4,727 \\
\text { households, reduced to } \\
\text { 3,500 households by } 1995 \text {. }\end{array}$ & $\begin{array}{l}\text { LFP: four categories } \\
\text { 1. employed } \\
\text { 2. early retirement } \\
\text { 3. unemployment } \\
\text { insurance } \\
\text { 4. disability insurance. } \\
\text { Health: self- reported } \\
\text { subjective health measure, } \\
\text { health limitation (first } \\
\text { wave) } \\
\text { - objective HSCL } \\
\text { - cleanset health index } \\
\text { derived during the } \\
\text { simultaneous estimation of } \\
\text { three equations }\end{array}$ & $\begin{array}{l}\text { - Reduced-form model } \\
\text { - Simultaneous estimation } \\
\text { of three equations } \\
\text { 1) participation equation } \\
\text { - multinomial logit } \\
\text { 2) health reporting } \\
\text { equation - ordered } \\
\text { probit } \\
\text { 3) health production } \\
\text { equation - linear } \\
\text { random effects }\end{array}$ & $\begin{array}{l}\text { Rescaled coefficient of } \\
\text { cleanset probability of bad } \\
\text { health measure in } \\
\text { participation equation } \\
\text { (multinomial logit model } \\
\text { with workers as reference } \\
\text { category): unemployed - } \\
\text { 2.131 [-8.51]; disabled - } \\
2.261 \text { [-9.76], -0.571 } \\
\text { [-6.28]. } \\
\text { Coefficient of bad health } \\
\text { dummy in multinomial logit } \\
\text { model not taking into } \\
\text { account endogeneity: } \\
\text { unemployed: -0.826 } \\
\text { [-3.6]; disabled -4.179 } \\
\text { [-17.25], -0.511 [-2.13] }\end{array}$ \\
\hline
\end{tabular}

$* * *=$ significant at the $1 \%$ level, $* *=$ significant at the $5 \%$ level, $*=$ significant at the $10 \%$ level.

Table A.2 Results for the US using an individual approach

\begin{tabular}{|c|c|c|c|}
\hline Author, dataset and sample & $\begin{array}{l}\text { Labour force participation } \\
\text { (LFP) and health measures }\end{array}$ & $\begin{array}{l}\text { Estimation } \\
\text { technique }\end{array}$ & Results \\
\hline $\begin{array}{l}\text { Author: Bound (1991) } \\
\text { Dataset: RHS, first wave } \\
\text { (1969) } \\
\text { Sample }(6,022) \text { : men, aged } \\
58 \text { to } 63 \text { in } 1969 \text { who worked } \\
\text { or were working for the } \\
\text { private sector }\end{array}$ & $\begin{array}{l}\text { LFP: participation during the } \\
1969 \text { survey week (dummy: } 1 \\
\text { is in the labour force) } \\
\text { Health: } \\
\text { - subjective health } \\
\text { (dummy } 1 \text { if health is } \\
\text { good or better than } \\
\text { average) } \\
\text { - functional limitations at } \\
\text { work (dummy) } \\
\text { - mortality (seven ordered } \\
\text { categories, higher values } \\
\text { correspond to later } \\
\text { mortality) }\end{array}$ & $\begin{array}{l}\text { - Reduced-form model } \\
\text { - Simultaneous system with } \\
\text { unobserved LFP, health and } \\
\text { mortality (identification } \\
\text { from parameter restrictions) } \\
\text { - OLS for LFP } \\
\text { - IV for LFP }\end{array}$ & $\begin{array}{l}\text { Marginal effect of health } \\
\text { variable on LFP (OLS, IV, } \\
\text { system) } \\
\text { - poor health }(-1.45,0.84, \\
0.50 \text { to } 0.76) \\
\text { - limits (-1.37, 0.91, } 0.51 \text { to } \\
0.76) \\
\text { - mortality (OLS): } 1974-1979 \\
(-0.26) \\
1973(-0.31) \\
1972(-0.52) \\
1971(-0.92) \\
1970(-0.95) \\
1969(-1.02)\end{array}$ \\
\hline $\begin{array}{l}\text { Authors: Bound et al. (1999) } \\
\text { Dataset: HRS, first three } \\
\text { waves (1992-96) } \\
\text { Sample }(6,701): \text { men }(2,875) \\
\text { and women }(3,826) \text { aged } 51 \\
\text { to } 61 \text { in the first wave and } \\
\text { employed in the second wave }\end{array}$ & $\begin{array}{l}\text { Analysis by gender } \\
\text { LFP: four categories of } \\
\text { labour force status transitions } \\
\text { between the second and third } \\
\text { waves: } \\
\text { 1) applied for DI } \\
\text { 2) emp. at the same job } \\
\text { 3) emp. at a different job } \\
\text { 4) neither emp. nor applied } \\
\text { for DI } \\
\text { Health: } \\
\text { - Lagged health } \\
\text { - Self-rated health } \\
\text { - Health limits ability to } \\
\text { - work } \\
\text { - ADL/IADL index } \\
\text { - Prevalence of various } \\
\text { chronic diseases }\end{array}$ & $\begin{array}{l}\text { Joint estimation of seven } \\
\text { equations: simulated ML } \\
\text { estimation } \\
\text { 1) latent variable model to } \\
\text { construct an index of } \\
\text { health in each wave } \\
\text { 2) (three ordered probit } \\
\text { models) } \\
\text { 3) three multinomial probit } \\
\text { models (base case: } \\
\text { working for the same } \\
\text { employer) } \\
\text { 4) equation of baseline work } \\
\text { status }\end{array}$ & $\begin{array}{l}\text { Coefficients of health } \\
\text { variables on labour force } \\
\text { transitions (different job, have } \\
\text { applied for disability } \\
\text { insurance (DI), not employed } \\
\text { and have not applied for DI): } \\
\text { *Men } \\
\text { - contemporaneous health: } \\
\text { (0.27, 1.83, 0.91) } \\
\text { - once lagged health: } \\
\text { (-0.03, -0.47, -0.42) } \\
\text { - twice lagged health: } \\
(-0.20,-0.61,-0.32) \\
\text { *Women } \\
\text { - contemporaneous health: } \\
\text { ( } 0.27,1.58,0.47) \\
\text { - once lagged health: } \\
(0.31,-0.24,-0.01) \\
\text { - twice lagged health: } \\
(-0.50,-0.55,-0.28)\end{array}$ \\
\hline
\end{tabular}




\begin{tabular}{|c|c|c|c|}
\hline $\begin{array}{l}\text { Authors: Dwyer \& Mitchell } \\
\text { (1999) } \\
\text { Dataset: HRS, first wave } \\
\text { (1992) } \\
\text { Sample: men, aged } 51 \text { to } 61 \\
\text { in } 1992\end{array}$ & $\begin{array}{l}\text { LFP: expected age of } \\
\text { retirement } \\
\text { Health: five different } \\
\text { measures plus specific health } \\
\text { conditions } \\
\text { - Work limitations } \\
\text { - Self-rated poor health } \\
\text { - Health conditions index } \\
\text { - ADL/IADL/FL index } \\
\text { - Dichotomous } \\
\text { ADL/IADL/FL } \\
\text { Instruments for health: } \\
\text { - Hospital nights } \\
\text { - Weight/height } \\
\text { - Parent died young } \\
\text { - Parent needs help } \\
\text { - Parent illness prior to } \\
\text { - } \text { mortality } \\
\text { - Narent alive } \\
\text { - Age of children }\end{array}$ & $\begin{array}{l}\text { - } \text { OLS } \\
\text { - IV estimates } \\
\text { - cross section } \\
\text { for the first wave } \\
\text { - Changes over two waves }\end{array}$ & $\begin{array}{l}\text { Poor health is associated with } \\
\text { earlier retirement } \\
\text { plans } \\
\text { Functional limitations result } \\
\text { in earlier than expected } \\
\text { retirement by one to two } \\
\text { years } \\
\text { Self-rated health measures } \\
\text { are not endogenously } \\
\text { determined with labour } \\
\text { supply and seem not to be } \\
\text { correlated with compensation } \\
\text { variables } \\
\text { Little evidence of } \\
\text { measurement error in the } \\
\text { more objective health } \\
\text { measures }\end{array}$ \\
\hline $\begin{array}{l}\text { Author: McGarry (2004) } \\
\text { Dataset: HRS (1992-94, two } \\
\text { waves) biennial survey data } \\
\text { Sample: men and women, } \\
\text { employed (not the self- } \\
\text { employed or those in the } \\
\text { military); final sample } \\
\text { consists of 5,498 observations }\end{array}$ & $\begin{array}{l}\text { LFP: } \\
\text { Expected probability of full- } \\
\text { time work at age } 62(\mathrm{C}) \text {, } \\
\text { Expected probability of } \\
\text { full-time work at age } 62(\mathrm{C}) \text {, } \\
\text { Health: } \\
\text { - Subjective health measure } \\
\text { - Subjective survival } \\
\text { probability to live to age } \\
\text { - } 85 \\
\text { - Lagged health } \\
\text { - Diseases } \\
\text { - Activity limitations } \\
\text { - hultiple measures of } \\
\text { health } \\
\text {. above health variables }\end{array}$ & Reduced-form model OLS & $\begin{array}{l}\text { * Effect of health on } \\
\text { probability of working } \\
\text { full-time at age } 62- \\
\text { - Baseline (reference } \\
\text { excellent health) } \\
\text { very good health: } \\
(-0.011) \text { [sd:0.013]; } \\
\text { good health: (-0.032) } \\
\text { [sd:0.014]; } \\
\text { fair and poor health: } \\
\text { (-0.082) [sd:0.019] } \\
\text { - Subjective survival } \\
\text { probability to live to age } \\
\text { 85: (0.102) [sd:0.017] } \\
\text { - Any disease condition: } \\
\text { (-0.035) [sd:0.011] } \\
\text { Activity limitations: } \\
\text { (-0.010) [sd:0.003 ] } \\
\text { Baseline effect of changes } \\
\text { in health on changes in } \\
\text { probability of working } \\
\text { full-time at age 62: } \\
\text { subjective health better } \\
\text { than last period (reference } \\
\text { same health than last } \\
\text { period) (0.013) [sd:0.018]; } \\
\text { health worse than last } \\
\text { period (-0.041) [sd:0.019] }\end{array}$ \\
\hline
\end{tabular}


Table A.3 Results for couple approaches

\begin{tabular}{|c|c|c|c|}
\hline $\begin{array}{c}\text { Author, dataset and } \\
\text { sample }\end{array}$ & $\begin{array}{c}\text { Labour force } \\
\text { participation (LFP) and } \\
\text { health measures }\end{array}$ & $\begin{array}{l}\text { Estimation } \\
\text { technique }\end{array}$ & Results \\
\hline \multicolumn{4}{|c|}{ European Union } \\
\hline $\begin{array}{l}\text { Authors: Blau and } \\
\text { Riphahn (1999) } \\
\text { Dataset: GSOEP, monthly } \\
\text { data } \\
\text { Sample: married couples } \\
\text { with at least one spouse } \\
\text { aged 50 to } 69 \quad(1,553 \\
\text { couples) }\end{array}$ & $\begin{array}{l}\text { LFP: transitions } \\
\text { between LF-states (D) } \\
\text { Health: } \\
\text { - Subjective health } \\
\text { satisfaction, } \\
\text { - Chronic disease }\end{array}$ & $\begin{array}{l}\text { Competing risks } \\
\text { hazard model }\end{array}$ & $\begin{array}{l}\text { Simulated effect of chronic } \\
\text { disease dummy husband (H) } \\
\text { and wife (W) } \\
\text { From both employed to } \\
\text { husband employed and wife } \\
\text { out of labour force (OLF) } \\
\text { (H:-0.0002, } \\
\text { W: } 0.0002 \text { ), or to wife } \\
\text { employed, husband OLF } \\
\text { (H:0.0001, } \\
\text { W: - } 0.0007) \\
\text { From husband employed } \\
\text { and wife OLF to both } \\
\text { employed (H:0.0001, } \\
\text { W: } 0.0032) \text {, or to both OLF } \\
\text { (H:0.0003, } \\
\text { W: - } 0.0018) \\
\text { From wife employed and } \\
\text { husband OLF to both } \\
\text { employed } \\
\text { (H:-0.0066, } \\
\text { W: - } 0.0009 \text { ), or to both OLF } \\
\text { (H:0.0036, } \\
\text { W: } 0.0017 \text { ) } \\
\text { From both OLF to husband } \\
\text { employed and wife OLF } \\
\text { (H:-0.0024, } \\
\text { W: - } 0.0007 \text {, } \\
\text { or to wife employed } \\
\text { and husband OLF } \\
\text { (H:-0.0004, } \\
\text { W: - } 0.0010 \text { ) }\end{array}$ \\
\hline $\begin{array}{l}\text { Authors: Jiménéz-Martín et } \\
\text { al. (1999) } \\
\text { Dataset: ECHP (1994-1995), } \\
\text { two waves, 10 European } \\
\text { countries: DK, BE, LU, FR, } \\
\text { UK, IR, IT, GR, ES, PL } \\
\text { Sample: couples }\end{array}$ & $\begin{array}{l}\text { LFP: } \\
\text { - Couple dummy that } \\
\text { captures transition } \\
\text { information of both } \\
\text { spouses } \\
\text { - Three initial states of } \\
\text { couple dummy } \\
\text { - Two possible states per } \\
\text { spouse: in the labour force } \\
\text { and out of the labour force } \\
\text { Health: } \\
\text { - Subjective health } \\
\text { - Subj. good health dummy } \\
\text { - Chronic illness } \\
\text { - Being admitted as a } \\
\text { - } \text { patient in a hospital } \\
\text { - Doctor visits }\end{array}$ & $\begin{array}{l}\text { Family utility model } \\
\text { Depending on the origin state } \\
\text { of both spouses estimate: } \\
\text { 1) Multinomial logit } \\
\text { 2) Logit model } 1 \\
\text { 3) Logit model } 2\end{array}$ & $\begin{array}{l}\text { * Coeff. of health variable } \\
\text { in the ind. approach: } \\
\text { - Good health } \\
\text { (men:-0.089 [0.099], } \\
\text { women: }-0.205 \text { [0.107]) } \\
\text { - Chronic problems (men: } \\
0.563 \text { [0.100], } \\
\text { women: } 0.229 \text { [0.113]) } \\
\text { - Hospital dummy } \\
\text { (men: } 0.647 \text { [0.128], } \\
\text { women: } 0.169 \text { [0.169]) } \\
\text { - Doctor visits } 1-5 \\
\text { (men: } 0.139[0.123], \\
\text { women: }-0.201[0.141] \text { ) } \\
\text { - Doctor visits 6+ } \\
\text { (men: } 0.345[0.148], \\
\text { women: }-0.139[0.161] \text { ) }\end{array}$ \\
\hline
\end{tabular}




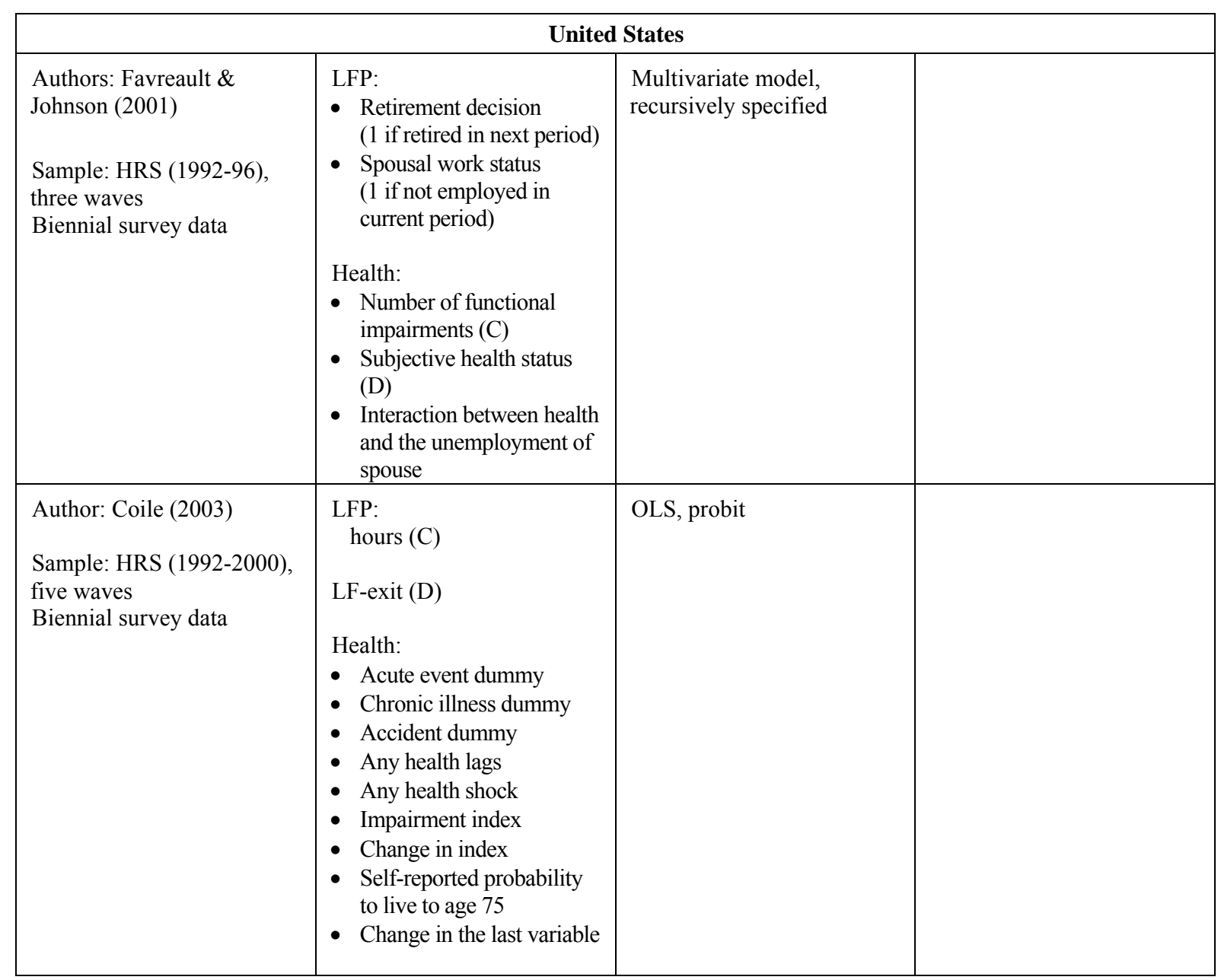




\section{Appendix B List of the Health Variables Used}

\section{Self-reported measures of health}

Subjective health. This is the self-reported answer to the question: How is your health? (very good, good, normal, bad and very bad). Previous studies have found very different effects for financial variables on labour force participation when subjective health status is replaced with data on eventual mortality. McGarry (2004), however, has had to conclude that changes in the included measure of health do not affect the estimated effects of income and wealth. In some surveys (such as the BHP until 1998) health status questions ask the respondents to compare their health with other persons of their age (Is your health better, worse or the same as that of other people of your age?). The likely expected decline in health status as the panel ages should therefore not be picked up. In that case a significant coefficient on that health variable should be interpreted as indicating that individualspecific variations in health have an impact on labour market activity.

\section{Objective measures of health}

Health conditions index. An index that counts the number of health conditions the respondent reports, including a wide range of functional limitations, chronic physical and mental disorders, and acute illness. This measure does not account for the severity of conditions experienced and uses the same weights for each condition. Since the variable is a count of conditions that are not likely to be independent, people with more severe symptoms tend to score higher.

Health utility index (HUI). A generic measure of health utility (McMaster Health Utility Index Mark III) is used to compute healthy life expectancies. This measure relies on self-reporting. One advantage is that respondents are only required to classify themselves by eight health attributes. The overall individual health utility score on a scale of zero to one is derived by using weights that are obtained from a different valuation survey on a different sample of individuals. As such, it represents a more valid and reliable general health measure than the single self-assessed health SAH question.

Hopkins Symptom Checklist (HSCL). The HSCL is a validated objective test of general health used in medical science to assess the psycho-neurotic and somatic pathology of patients. The HSCL consists of 57 items and is known to have an excellent rate of external consistency, meaning that the test results are highly correlated with objective medical reports on the patient's health status. The responses result in a mental score, a physical score and a total health score. The advantage of this indicator in comparison with a subjective self-assessed health measure is that it is less sensitive to reporting errors that may depend upon the respondent's labour market status.

Mortality. The eventual mortality of the individual has been used in past work. As a proxy for health it could affect the utility/disutility of employment or leisure. Second, a longer life span means ceteris paribus a longer potential retirement over which a worker must finance consumption and thus a need for greater retirement assets. An alternative measure here can be the expected probability to live to a certain old age.

Date of subsequent mortality. This is a commonly used proxy that is bound to be imperfectly correlated with health status. Even a moderate account of measurement error in such proxies can easily lead to the conclusion that the self-reported measure will give a more accurate picture of the impact of health and financial incentives on labour supply.

Lagged health. One measure of lagged health is subjective health in the period prior to observed retirement. Lagged health is generally found to have a smaller effect on retirement than postretirement health status. This could indicate that individuals alter their subjective reports of health based on their labour status or alternatively that retirement is caused by health shocks that are not observable in the pre-retirement interview. 
Diseases. Another measure of health that can be used is the objective reports of specific conditions. These reports are typically answers to the question: Has a doctor ever told you that you have the following diseases? The conditions vary from acute events to chronic conditions. As most conditions are rare their effects can be difficult to identify. When those measures are replaced with a summary measure indicating the diagnosis of any condition the effect becomes significant.

Activity limitations or the presence of work limitations. Other measures used are responses to subjective questions about whether the respondent's health limits his or her ability to work. As in the case of selfreported health status, these reported work limitations may suffer from justification bias. It may therefore be better to use measures of more general activity limitations or an indicator of different activities. Many researchers have expressed that endogeneity is more of a problem with functional limits than with subjective health (Bound, 1991, p. 122).

Activities of daily living ( $A D L)$. These functional limitation measures are more closely tied to the functional capacity for work and assess the respondents' difficulty with performing 17 activities of daily living and instrumental activities of daily living IADL. There are also variables that are based on ADL/IADL/FC (functional capacity), which can be expressed as a dichotomous variable (1 if there is one positive answer) or as a hierarchical index (an 11-category index increasing in the severity of ADLs, IADLs and FLs).

Health shocks (changes over time). The use of health shocks as an alternative to self-reported health status is appealing, owing to the concern that health status may not be independent of labour force outcomes if individuals seek to rationalise their retirement status by claiming a health problem.

Health instruments. These include hospital nights (count of the number of nights spent in a hospital last year), weight/height ratio, mother died young, mother/father needs help, mother/father were sick prior to mortality, mother/father are alive, number of children and age. 


\section{Appendix C \\ Overview of the Available Databases}

\section{United States}

Retirement History Survey (RHS). This survey follows a sample of men and unmarried women born between 1906 and 1911 for ten years (1969-79).

New Beneficiary Survey (NBS). This survey was conducted by the Social Security Administration in 1992. The NBS surveyed persons born between 1910 and 1918, slightly later than the cohort interviewed by the RHS.

Health and Retirement Study (HRS). The Michigan Survey Center's recent, nationally representative survey of the young elderly gives extensive information on health, labour force status and demographics. The six waves (1992-2002) of the survey have been conducted every two years since 1992 and contain persons born between 1931 and 1941 (aged 51-61 in 1992) and their spouses.

\section{European Union}

The Centre for Economic Research on Retirement and Ageing Panel Survey (CERRA panel). This panel survey is a Dutch project that is designed specifically for the analysis of the effects of ageing on the labour market and resembles the HRS. The two-wave panel was conducted in 1993 and 1995 (by the University of Leiden). The first wave consisted of 4,727 households in which the head of the household was aged between 43 and 63 at the date of the interview. In each household, both the head and the partner, if present, were interviewed. In the autumn of 1995, the same respondents were contacted for a second interview. Approximately $74 \%$ of the first wave respondents participated in the second wave, which resulted in about 3,500 households. For each wave, extensive information was obtained on labour history and current labour market status, sources of income, attitude towards retirement, housing, health and a variety of socio-economic variables. The health variables in the sample contain, among others, commonly used subjective measures and responses to the Hopkins Symptom Checklist (HSCL).

Dutch Socio-Economic Panel (SEP). This survey covered 17 waves from 1984 to 2000. It was conducted by Statistics Netherlands and covered approximately 5,000 households per year. In structure and content this panel survey is similar to the GSOEP and the American PSID. The aim of the SEP is to provide a description of the most important elements of individual and household welfare and to monitor changes in these elements over time. As such this survey is not specifically designed to cover retirement issues per se.

German Socio-Economic Panel (GSOEP). This important panel currently consists of 20 waves (19842003) of data for more than 6,000 German households. The panel includes the standard health variables such as a measure of subjective health satisfaction, the presence and degree of an officially recognised handicap and the presence of a chronic disease. Extra health variables have recently been added.

European Community Household Panel (ECHP). This dataset contains eight waves that have been released from 1994 to 2001 for most EU countries. The same questionnaire is adopted by the national data collection units in each participating country. The advantage of these country data is their high comparability level. The survey is composed of a household and a personal file, and the same individuals and families are interviewed over time. In the first wave (in 1994), a sample of some 60,500 nationally representative households - approximately 130,000 adults aged 16 and older - were interviewed in the EU member states. Austria (1995) and Finland (1996) have joined the project since then. For the fourth wave of the ECHP (in 1997), the original ECHP surveys were stopped in three countries, namely Germany, Luxembourg and the United Kingdom. In these countries, existing national panels were used and comparable data were derived from the GSOEP and BHPS - starting from 1994 onwards. 
British Household Panel Survey (BHPS). The eight waves of this survey from 1991 to 1998 provide a sample that was selected to be representative of the population of England, Wales and Scotland (south of the Caledonian Canal). The question relating to health status changed in 1999.

Survey of Health, Aging and Retirement in Europe (SHARE). This project will build up a fundamental resource for science and public policy to help master the challenge of population ageing. The main aim of SHARE is to create a pan-European interdisciplinary panel dataset covering persons aged 50 and older. The project brings together many disciplines, including epidemiology, sociology, statistics, psychology, demography and economics. Scientists from some 15 countries work on feasibility studies, experiments and instrument development, culminating in a survey of about 22,000 individuals. The multidisciplinary nature of the data will provide new insights in the complex interactions between economic, health, psychological and social factors determining the quality of life of the elderly.

Health 2000. This study involves a cross-section of Finnish health data for the year 2000. An extensive list of health data is available. 
Appendix D

Relation between Health and Labour Force Participation

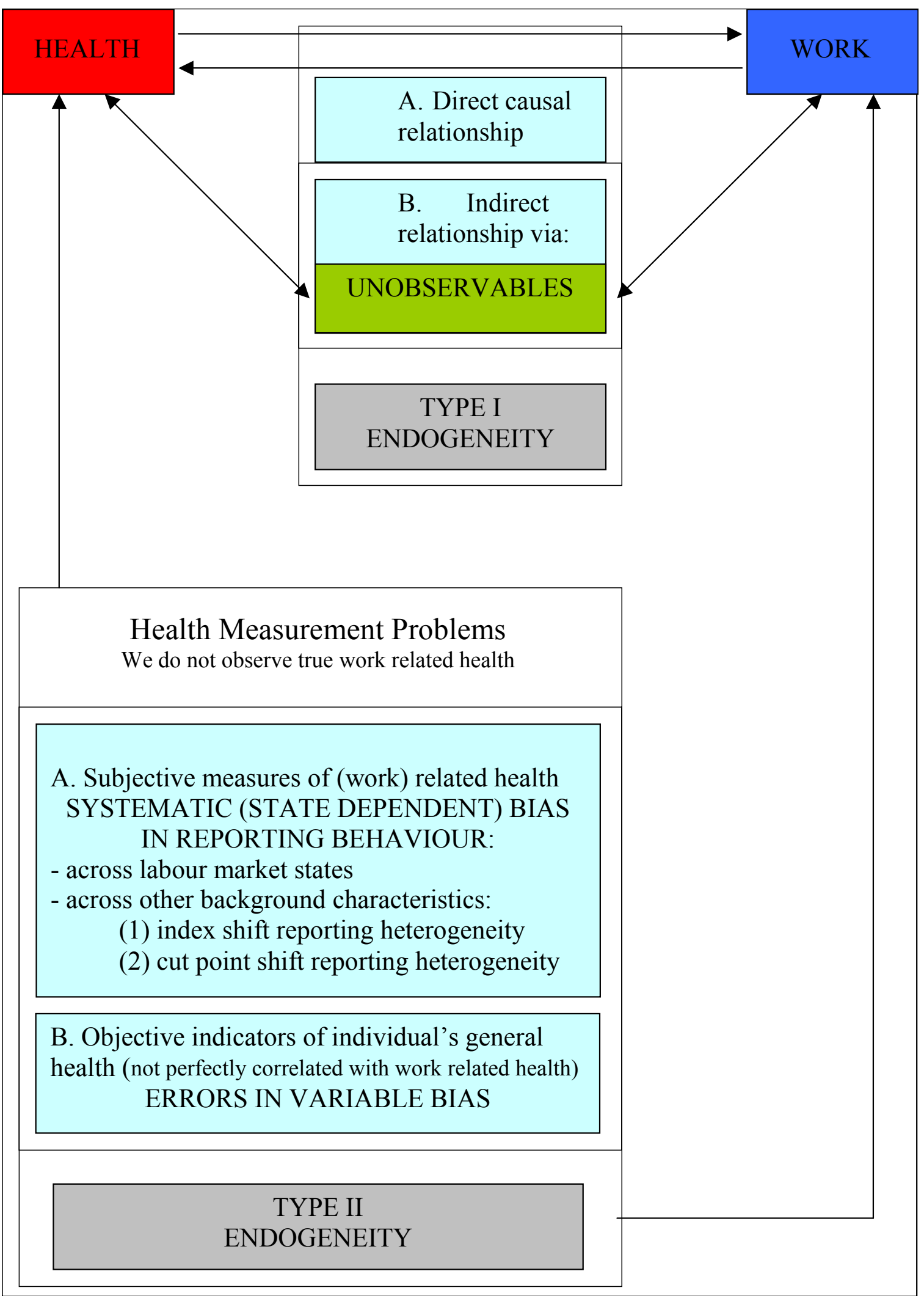




\section{AGI R - Ageing, Health and Retirement in Europe}

AGI $\mathbf{R}$ is the title of a major study on the process of population ageing in Europe and its future economic consequences. This project was motivated by an interest in verifying whether people are not only living longer but also in better health. It aims at analysing how the economic impact of population ageing could vary when not only demographic factors, but also health developments are taken into consideration. The project started in January 2002 for a period of three years.

The principal objectives of the study are to:

- document developments in the health of the elderly, ideally since 1950, based on a systematic collection of existing national data on the health and morbidity of different cohorts of the population;

- analyse retirement decisions and the demand for health care as a function of age, health and the utility of work and leisure;

- combine these results, and on that basis to elaborate scenarios for the future evolution of expenditure on health care and pensions; and

- analyse the potential macroeconomic consequences of different measures aiming at improving the sustainability of the European pension systems.

The AGI R project is carried out by a consortium of nine European research institutes, most of which are members of ENEPRI:

- CEPS (Centre for European Policy Studies), Brussels

- CEPII (Centre d'Etudes Prospectives et d'Informations Internationales), Paris

- CPB (Netherlands Bureau for Economic Policy Analysis), The Hague

- DIW (Deutsches Institut für Wirtschaftsforschung), Berlin

- ETLA (the Research Institute of the Finnish Economy), Helsinki

- FEDEA (Fundación de Estudios de Economía Aplicada), Madrid

- FPB (Belgian Federal Planning Bureau), Brussels

- NI ESR (National Institute for Economic and Social Research), London

- LEGOS (Laboratoire d'Economie et de Gestion des Organisations de Santé, Université de Paris-Dauphine), Paris

It has received finance from the European Commission, under the Quality of Life Programme of the $5^{\text {th }}$ EU Research Framework Programme. The project is coordinated by Jorgen Mortensen, Associate Senior Research Fellow at CEPS. For further information, contact him at: jorgen.mortensen@ceps.be. 


\section{REVI SER - Research Training Network on Health, Ageing and Retirement}

REVISER was launched by several members of the ENEPRI network in August 2003. The project was financed under the programme on Improving the Human Research Potential $\&$ the Socio-Economic Knowledge Base of the $5^{\text {th }}$ EU Research Framework Programme.

The REVISER project finances training stays for young researchers in the following six research institutes:

- CEPS (Centre for European Policy Studies), Brussels

- CPB (Netherlands Bureau for Economic Policy Analysis), The Hague

- DIW (Deutsches Institut für Wirtschaftsforschung), Berlin

- ETLA (the Research Institute of the Finnish Economy), Helsinki

- FEDEA (Fundación de Estudios de Economía Aplicada), Madrid

- LEGOS (Laboratoire d'Economie et de Gestion des Organisations de Santé, Université de Paris-Dauphine), Paris

Trainees participate in research conducted in the areas of population ageing, health and retirement in the institutes in which they are placed, often in the context of common research projects developed by consortiums of ENEPRI partners. Trainees must be nationals of an EU member state or associated state, or must have resided in the EU for at least five years immediately prior to their appointment. This network aims at fostering the mobility of researchers. Thus, trainees must not be nationals of the state in which the institute appointing them is located and must not have carried out their normal activities in that state for more than 12 of the 24 months prior to the appointment.

This project is coordinated by Jorgen Mortensen, Associate Senior Research Fellow at CEPS. For further information, contact him at: jorgen.mortensen@ceps.be. 


\section{About ENEPRI}

$\mathrm{T}$ he European Network of Economic Policy Research Institutes (ENEPRI) is composed of leading socio-economic research institutes in practically all EU member states and candidate countries that are committed to working together to develop and consolidate a European agenda of research. ENEPRI was launched in 2000 by the Brussels-based Centre for European Policy Studies (CEPS), which provides overall coordination for the initiative.

While the European construction has made gigantic steps forward in the recent past, the European dimension of research seems to have been overlooked. The provision of economic analysis at the European level, however, is a fundamental prerequisite to the successful understanding of the achievements and challenges that lie ahead. ENEPRI aims to fill this gap by pooling the research efforts of its different member institutes in their respective areas of specialisation and to encourage an explicit European-wide approach.

ENEPRI is composed of the following member institutes:

CASE Center for Social and Economic Research, Warsaw, Poland

CEPII Centre d'Études Prospectives et d'Informations Internationales, Paris, France

CEPS Centre for European Policy Studies, Brussels, Belgium

CERGE-EI Centre for Economic Research and Graduated Education, Charles University, Prague, Czech Republic

CPB Netherlands Bureau for Economic Policy Analysis, The Hague, The Netherlands

DIW Deutsches Institut für Wirtschaftsforschung, Berlin, Germany

ESRI Economic and Social Research Institute, Dublin, Ireland

ETLA Research Institute for the Finnish Economy, Helsinki, Finland

FEDEA Fundación de Estudios de Economía Aplicada, Madrid, Spain

FPB Federal Planning Bureau, Brussels, Belgium

IE-BAS Institute of Economics, Bulgarian Academy of Sciences, Sofia, Bulgaria

IER Institute for Economic Research, Ljubljana, Slovenia

IHS Institute for Advanced Studies, Vienna, Austria

ISAE Istituto di Studi e Analisi Economica, Rome, Italy

ISWE-SAS Institute for Slovak and World Economy, Bratislava, Slovakia

NIER National Institute of Economic Research, Stockholm, Sweden

NIESR National Institute of Economic and Social Research, London, UK

NOBE Niezalezny Osrodek Bana Ekonomicznych, Lodz, Poland

PRAXIS Center for Policy Studies, Tallinn, Estonia

RCEP Romanian Centre for Economic Policies, Bucharest, Romania

TÁRKI Social Research Centre Inc., Budapest, Hungary

ENEPRI Research Reports are designed to make the results of research projects undertaken within the ENEPRI framework publicly available. The findings and conclusions should be attributed to the author and not to the ENEPRI network as such.

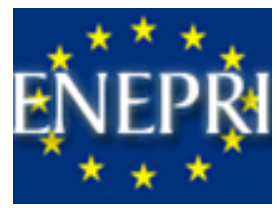

